Іващенко А. М., к.т.н., доцент, (ORCID: 0000-0002-8131-5463);

Возняк С. М., к.т.н., с.н.c, (ORCID: 0000-0002-9015-813X);

Полякова O. B., (ORCID: 0000-0003-4370-2187)

Зайцев М. М., к.ю.н.

Центр воєнно-стратегічних досліджень Національного університету оборони України імені Івана Черняховського, Київ

\title{
Аналіз можливих форм і способів проведення миротворчої операції ООН на Сході України
}

Резюме. Проводиться аналіз спроможностей ООН щодо проведення миротворчої операції для врегулювання конфлікту на Сході України.

Ключові слова: конфлікт на Сході України; ООН; миротворча операція.

Постановка проблеми. На початку 2018 року ООН зробила заяву, що для врегулювання ситуації на Донбасі потрібно ввести миротворчі сили. Миротворці мають бути відібрані з європейських країн, які мають досвід проведення подібних операцій та яким довіряє Росія [1]. Разом 3 тим залишаються невирішеними міжнародно-правові питання щодо розгортання миротворчої операції на Сході України: кого і на якій лінії повинен розділити миротворчий контингент, легітимізація миротворчої операції, країни, які нададуть миротворчі контингенти.

Аналіз основних досліджень i публікацій. Форми і способи проведення миротворчої операції під егідою $\mathrm{OOH}$ на території окупованого Донбасу активно обговорюється українськими i зарубіжними експертами та політиками як реальний спосіб припинення воєнного конфлікту. Платформою для їх визначення стала 54 Міжнародна конференція з безпеки, що відбулася 16-18 лютого в Мюнхені [2]. Тема розміщення сил $\mathrm{OOH}$ на Сході України була докладно обговорена під час панельних дискусій, двосторонніх зустрічей, у кулуарах форуму, наслідком чого стали відповідні політичні заяви й експертні висновки. Також була представлена доповідь Вашингтонського інституту Хадсона, що стала першою спробою комплексного аналізу спроможностей $\mathrm{OOH}$ щодо розгортання миротворчої місії на Сході України. Доповідь було підготовлено під егідою фонду колишнього Генсека НАТО А. Фог Расмуссена, радника Президента України П. Порошенка. Автором доповіді є експерт ООН Р. Говен [3].

Метою статті $\epsilon$ аналіз і оцінювання можливих форм i способів проведення миротворчої операції на Сході України.
Виклад основного матеріалу. Статут $\mathrm{OOH}$, як і практика класичних миротворчих операцій, створювалися для врегулювання відносин таких міжнародних суб'єктів, як визнані держави, тому прийнятним i природним для $\mathrm{OOH} \in$ розміщення миротворчих сил на офіційному кордоні України і Російської Федерації (РФ). Саме так бачить миротворчу операцію українська сторона i визнає РФ стороною конфлікту. Окупаційна адміністрація у Донецькій та Луганській областях не вважається правомочним суб' єктом [4]. Розміщення миротворчих сил на кордоні дасть змогу припинити підтримку сепаратистів зброєю, боєприпасами, направлення воєнних радників i добровольців 3 російської території на територію України. РФ не вважає себе стороною конфлікту та пропонує інший підхід.

Позиція РФ полягає в розділі конфліктуючих сторін там, де має місце зіткнення протиборчих сил, по фактичній лінії зіткнення. Ця лінія не є кордоном держав, але від неї йде відлік в Мінських угодах [5], і вона, тим самим, $\epsilon$ де-факто визнаною лінією протиборства. Саме навколо цієї лінії відбуваються постійні порушення режиму припинення вогню. Це означає, що потенційні миротворці, якщо будуть спрямовані в зону конфлікту, 3'являться в глибині офіційної української території. Їх присутність надасть "заморожуючу" функцію i не дозволить Збройним Силам України проводити заходи із забезпечення національної безпеки і оборони та поверненню контролю над тимчасово окупованими територіями у Донецькій та Луганській областях. Зі зрозумілих причин таке розміщення миротворців не влаштовує Україну. 
Існує два основних типи операцій $\mathrm{OOH} 3$ погляду їх правової легітимізації. Перший операчї з підтримання миру (peacekeeping), які проводяться на основі принципів, закріплених у розділі VI Статуту ООН. Цей тип миротворчих операцій потребує документованої згоди легітимного керівництва сторін конфлікту на втручання 3 боку міжнародного співтовариства. У подібному випадку операція може бути проведена в тому числі регіональними міждержавними організаціями, права яких закріплені в главі VIII Статуту ОOH, у взаємодії з $\mathrm{OOH}$ або самостійно; при цьому мандат з боку РБ $\mathrm{OOH}$ $\epsilon$ бажаним, але його може і не бути.

Другий - операції по встановленню миру (peace enforcement), проводяться на основі закріплених у розділі VII Статуту $\mathrm{OOH}$ принципів силового втручання міжнародного співтовариства в особі ООН в конфлікти або внутрішні справи держав, у тому числі всупереч волі легітимної влади держави, на території якої відбувається конфлікт. Такі операції можуть проводитися тільки на основі мандата РБ ООН. Подібні операції отримали назву “політичні місії $\mathrm{OOH}^{\circ} \mathrm{i}$, як правило, містять елементи примусових силових дій. На відміну від миротворчих операцій ними керує Політичний департамент $\mathrm{OOH}, \mathrm{a}$ не Департамент операцій 3 підтримки миру. Фактично в подібних операціях $\mathrm{OOH}$ сама визначає політичні цілі та умови розв'язання конфлікту і задає параметри постконфліктного стану.

У разі конфлікту на Сході України проведення операції за принципами глави VI Статуту ООН можливо при виконанні таких умов:

направлення Україною в ООН офіційної згоди на проведення операції;

невизнана окупаційна адміністрація Російської Федерації у Донецькій та Луганській областях також висловлює згоду на втручання з боку світової спільноти в особі $\mathrm{OOH}$;

у разі винесення питання на розгляд РБ $\mathrm{OOH}$, РФ як постійний член РБ $\mathrm{OOH}$ не накладає вето на план миротворчої операції.

При виконанні тільки перших двох умов, проведення миротворчої операції в обхід РБ $\mathrm{OOH}$ може бути делеговано регіональним організаціям (наприклад, НАТО або ОБСС), 3 посиланням на наявність документованої згоди конфліктуючих сторін.

Проведення політичної місії $\mathrm{OOH} 3$ елементами примусових дій за принципами глави VII Статуту можливо лише в разі наявності відповідного мандату РБ ООН, для чого потрібна згода РФ та інших постійних i більшості непостійних членів РБ ООН, проте не потребує згоди України та окупаційної адміністрації у Донецькій та Луганській областях. Прикладами подібних миротворчих операцій ООН є операції в Боснії, Косово, Афганістані, Іраку, Лівії - усі вони проводилися за рішенням РБ ООН всупереч волі влади держав, на території яких відбувався конфлікт, i включали істотний силовий компонент і примусові дії. Однак у сучасних умовах існування режиму припинення вогню прийняття мандата $\mathrm{OOH}$ на силову операцію практично неможливо.

Якщо відбудеться повний зрив угод i повернення сторін до збройної протидії, ймовірність розгляду в ООН сценаріїв операції з примушення сторін до миру підвищиться.

Третя група проблем пов'язана 3 тим, хто міг би надати миротворчі контингенти для операції на Сході України. Представники окупаційної адміністрації неодноразово заявляли, що їх влаштовує залучення російського контингенту в якості миротворців, але це категорично заперечується українською стороною. У свою чергу залучення контингентів НАТО за мандатом ООН (подібно до того, як це робилося в колишній Югославії, Афганістані, Лівії) було б негативно сприйнято і відкидається російською стороною. Практика ООН вимагає направляти в конфліктні регіони контингенти тих країн, які не мають власних явних інтересів у регіоні конфлікту.

Можливість залучення Колективних миротворчих сил ОДКБ (створені в 2012-2014 pp. у кількості 3600 осіб), швидше за все, влаштувало б керівництво РФ, однак відкидається Україною в силу політичного домінування РФ в ОДКБ. До того ж залучення КМС ОДКБ майже однозначно не отримає консенсусної підтримки у керівництва деяких країн ОДКБ, перш за все тих, які мають актуальні або латентні проблеми із сепаратистськими силами на своїй території. Між тим, окремі російські експерти висловлювалися щодо потенціального залучення миротворчих контингентів Білорусі та Казахстану (не через механізм ОДКБ, а як індивідуальних країн-постачальників контингентів для підмандатних операцій $\mathrm{OOH}$ ) як держав, які виявили посередницькі навички i однозначно не встали на бік жодної зі сторін конфлікту.

У теперішній час триває перегляд базових принципів миротворчої діяльності 
$\mathrm{OOH}$, що матиме вплив на можливості застосування миротворчих сил ООН в Україні.

Підхід ООН до проведення миротворчих операцій у конфліктних регіонах еволюціонує $\mathrm{i}$ періодично істотно переглядається. У 2014-2015 pp. 3 ініціативи Генерального секретаря ООН було створено і працювала Незалежна група високого рівня 3 миротворчих операцій у складі 16 досвідчених дипломатів і військових 3 різних країн. У червні 2015 р. незалежна група 3 питань миротворчих операцій представила $\mathrm{OOH}$ i світовій спільноті доповідь із великими і надто радикальними рекомендаціями, яка отримала назву “Об' єднуючи наші сили заради миру політика, партнерство, люди" [6].

Однією 3 основних проблем сучасної миротворчої діяльності ООН у доповіді називається зростаючий розрив між очікуваннями світової спільноти (яке вважає, що втручання $\mathrm{OOH}$ у конфлікт у принципі має гарантувати його розв'язання) i реальною нездатністю триваючих десятиліттями операцій забезпечити політичне вирішення конфліктів. Нерідко операції з підтримки миру проводяться в умовах, коли немає або майже немає миру, який можна було б підтримати. У зв'язку з цим у доповіді обгрунтовується одна 3 рекомендацій, яку можна було б назвати закликом до “політизації” врегулювання конфліктів. Класичний підхід до миротворчості припускав, що завдання міжнародної спільноти, яку представляють $\mathrm{OOH}$, пасивна і складається в "заморожуванні" будь-якого конфлікту, припинення кровопролиття, роз'єднання сторін і надання сторонам "місця і часу” для врегулювання та подальшого досягнення політичного вирішення конфлікту. Водночас $\mathrm{OOH}$, відповідно до принципів неупередженості та рівновіддаленості від сторін конфлікту, не повинна займати будь-які політичні позиції щодо конфлікту або підтримувати будь-які із залучених до нього політичних сил. Незалежна група пропонує $\mathrm{OOH}$ зайняти набагато активнішу позицію лідерства в політичному врегулюванні, не лише підтримувати примирення, a i свідомо брати на себе лідерство у веденні переговорів, розробленні компромісів, досягненні політичного рішення. Іншими словами, $\mathrm{OOH}$ не слід витрачати сили i кошти на конфлікти, в яких конфліктуючі сторони не дають ООН стати провідною силою у врегулюванні. Якщо цієї ролі ведучого посередника у ООН немає, тоді створені $\mathrm{OOH}$ умови перемир'я можуть легко пропасти даремно, невизначеність i нерозв'язаність конфлікту тягнутимуться роками i десятиліттями, а ООН, витративши величезні зусилля i кошти, не зможе ні дочекатися врегулювання від самих конфліктуючих сторін, ні гідно згорнути операцію.

Такий підхід віддаляе перспективи втручання ООН із повноцінною миротворчою операцією на Сході України [7]. Власна чітка лінія $\mathrm{OOH}$ із планом політичного врегулювання може бути проведена швидше в тих конфліктах, у яких сторони конфлікту слабкі політично, а єдиний політичний вектор тиску 3 боку РБ ООН, навпаки, єдиний і сильний. Однак це не випадок конфлікту на Сході України: тут єдності політичних цілей серед членів РБ ООН немає.

Значне напруження у організаторів миротворчої діяльності ООН викликають ситуації, коли доводиться включати в операції завдання 3 протидії тероризму. Незалежна група високого рівня, яка проаналізувала систему миротворчості, вказує у своїй доповіді, що "місії ООН з підтримання миру в силу їх складу та характеру діяльності не пристосовані до ведення антитерористичних операцій. Вони не мають, зокрема, необхідного спеціального спорядження, розвідувальних даних, матеріально-технічного забезпечення, сил $\mathrm{i}$ засобів і спеціалізованої військової підготовки".

Виникає методологічне або доктринальне питання 3 організації операцій. У випадках, коли оперативна обстановка в зоні конфлікту потребує серйозного міжнародного силового втручання, застосування важких озброєнь або спеціальних підрозділів, Група високого рівня пропонує взагалі не застосовувати $\mathrm{OOH}$, a використовувати спеціально навчені сили кризового реагування окремих країн і коаліцій держав, або колективні постійні збройні сили регіональних організацій. Наприклад, НАТО сформувало в 2007 p. Сили швидкого реагування в кількості 20000 осіб (потім їх чисельність була збільшена) саме для швидкого розгортання військ у регіонах конфліктів. ОДКБ створила Колективні сили оперативного реагування (КСОР) у кількості 17000 , а у 2012 - 2015 років. - Колективні миротворчі сили (КМС) у кількості 3600 чоловік. Такі сили, на відміну від “збірних" контингентів $\mathrm{OOH}$, проходять регулярні спільні тренування, мають бригадну структуру 3 компонентами польової розвідки, транспортної авіації, піхоти, десантників, підрозділів хімічної і радіаційної розвідки, вони спираються на інфраструктурну підтримку генеральних штабів ряду країн [8]. 
Це $€$ різницею між “блакитними касками" (збірними підрозділами, переданими в розпорядження $\mathrm{OOH}$ і керованими з боку $\mathrm{OOH)} \mathrm{i} \mathrm{"зеленими} \mathrm{касками"} \mathrm{(представниками}$ національних армій, збройних сил держав, які паралельно 3 операцією $\mathrm{OOH}$, але під національним командуванням вводяться в регіон бойових дій). Прикладом є паралельне використання у 2001 - 2014 pp. американських військ (підпорядковувалися тільки американському військовому відомству) в операції США в Афганістані поруч (i паралельно) 3 операцією Міжнародних сил $\mathrm{OOH} \mathrm{в} \mathrm{Афганістані.}$

У разі конфлікту на Сході України регіон, який перейшов під контроль окупаційної адміністрації, оголошений “район здійснення заходів із забезпечення національної безпеки і оборони, відсічі й стримування збройної агресії Російської Федерації у Донецькій та Луганській областях". Це виключає $\mathrm{OOH} 3$ числа потенційних регуляторів або вимагає використання замість контингентів $\mathrm{OOH}$ підрозділів регіональних організацій - власне, у цьому регіоні таких боєздатних контингентів “зелених касок” всього три - це або підрозділ Сил реагування НАТО, або оперативнотактичне з'єднання Євросоюзу (CJTF), або Колективні миротворчі сили ОДКБ.

Однак використання "зелених касок" замість "блакитних" має і свої негативні аспекти. Зокрема, національні армійські частини зазвичай не проходять навчання в області прав людини, гуманітарного права, як персонал $\mathrm{OOH}$ вони натреновані стріляти "на знищення", а не неупереджено розділяти ворогуючі сторони. Використання "зелених касок” (звичайних армійських підрозділів) замість контингентів ООН призводить до підвищення ризику для мирного населення, збільшення числа жертв конфлікту, може призводити до масових порушень прав людини. Тим часом можна зрозуміти i експертів 3 Групи високого рівня, які закликають не ставити силові завдання, 3 якими можуть впоратися лише армійські підрозділи 3 відповідною технікою, озброєнням i тренуванням, “блакитним каскам”. Це призводить до збільшення числа жертв серед миротворців, зниження ймовірності адекватного рішення бойового завдання і як наслідок - підриву престижу OOH [9].

В останнє десятиліття в ООН приходять до практики з'єднання паралельних міжнародних, національних i регіональних операцій. Використовується термінологія створення “партнерств". Підкреслюється, що будь-яка миротворча операція $\mathrm{OOH}$ вже $\epsilon$, по суті, партнерством низки країн, які поєднують свої сили, кошти, війська, цивільний персонал для виконання спільних завдань. Природний розвиток таких партнерств передбачає підключення, наприклад, регіональних організацій (ОБСЄ, НАТО, СС, Африканського Союзу, Ліги арабських держав, ОДКБ та інших) до врегулювання. У деяких випадках, як це було в Афганістані та Іраку, доцільним $\epsilon$ паралельне з $\mathrm{OOH}$ розгортання національних армійських підрозділів групи держав під національним або коаліційним командуванням. Це підвищує гнучкість всього військовополіцейсько-цивільного конгломерату, який вирішує комплекс різнотипних завдань в регіоні конфлікту.

Таким чином, для вирішення конкретних завдань в контексті конфлікту на Сході України не підійде типова миротворча операція або політична місія $\mathrm{OOH}$, а потрібно саме створення індивідуально "скроєного" партнерства сил різних організацій i, можливо, окремих держав. Таке партнерство може включати політико-дипломатичну місію $\mathrm{OOH}$ i ОБСС, але у встановленні гарантованого поділу і насильницького розведення важких озброєнь сторін може спиратися на готові компоненти різнотипних сил кризового реагування, які могли б надати НАТО, ЄС і ОДКБ. Оскільки використання виключно силових компонентів країн Заходу (наприклад, тільки НАТО) або Сходу (наприклад, виключно ОДКБ) викликало б політичні протиріччя сторін, залишається важко реалізований сценарій 3'єднання контингентів різного походження під посередницьким політичним керівництвом OОН та/або ОБСЄ. Контингент ОДКБ, який має довіру з боку окупаційної адміністрації, міг би відповідати за роз'єднання і відведення важкої техніки з боку збройних формувань Російської Федерації, в той час як силові компоненти, надані ОДКБ, ЄС або НАТО, могли б контролювати ситуацію в коридорі між лініями дотику, позначеними в угодах "Мінськ1 " i “Мінськ-2".

Таке залучення комбінації силових компонентів має сенс виключно в разі, якщо йдеться про доведення до кінця мінського плану розведення ворогуючих сил по лініях зіткнення в глибині української території. На російсько-українському кордоні, який $\epsilon$ об'єктом потенційного миротворчого поділу, ніякі силові компоненти недоречні, тут бойові 
дії не ведуться, і з ситуацією впорається неозброєна спостережна місія.

Останніми роками відбулася певна модернізація організації поліцейських функцій в миротворчих операціях. Загальна пропорція поліцейських серед міжнародних миротворців перевищила близько $20 \%$ від контингентів. Були створені постійні резервні поліцейські сили для використання в миротворчих операціях. Замість збору окремих малих поліцейських груп із різних країн, було впроваджено принцип надання країнами цілісних сформованих поліцейських підрозділів, які укомплектовані, мають внутрішні командні органи, обладнання та озброєння і можуть негайно, без "притирання" компонентів один до одного, приступати до виконання завдань у регіоні конфлікту. У разі надання певних поліцейських функцій місії ОБСЄ в Україні знадобиться залучення саме таких сформованих поліцейських підрозділів, які могли б надати країни $\epsilon$, які забезпечують до $70 \%$ фінансування i укомплектування місії ОБСС. Водночас слід розуміти, що згідно з трактуванням характеру поліцейських функцій i регіону їx застосування між сторонами конфлікту залишаються невирішені протиріччя. Мається на увазі поступове взяття під контроль будьякими міжнародними силами (у цьому випадку поліцейськими підрозділами під егідою ОБСє) територій невизнаних республік, де такий контроль покликаний поступово замінити контролювання цих територій РФ.

Можна констатувати, що формування i проведення повномасштабної розділової операції міжнародної організації в Україні $\epsilon$ складним завданням. Така операція була гостро актуальною в період активного бойового зіткнення конфліктуючих збройних формувань у період другої половини 2014 першої половини 2015 pp. Тоді неодноразово складалися моменти в яких гостро не вистачало посередницьких функцій нейтральної “третьої сили” (збройних формувань під політичним керівництвом міжнародної організації або коаліції) для зниження інтенсивності конфлікту, захисту цивільних населення і запобігання загибелі та руйнувань.

На етапі після лютого 2015 р. спостереження за розведенням військ i відведенням важкої техніки в контексті угод "Мінськ-2" було доручено ОБСЄ. Наглядові функції цілком (хоча і 3 запізненням) були реалізовані неозброєними цивільними спостерігачами ОБСЄ. Однак затягування i періодична інверсія відведення важкої техніки, а також постійні масовані порушення режиму припинення вогню знову потребували іншого формату операції - 3 елементами примусових дій із залученням військових контингентів третьої сили 3 широким мандатом сили, щоб створити велику нейтральну зону між збройними формуваннями конфліктуючих сторін (за прикладом багатьох проведених миротворчих операцій). Однак і на цьому етапі політичний мандат потребував єдності думок у РБ ООН і в результаті узгоджений не був.

Не отримав підтримки з боку РБ ООН і ЄC і запит української сторони на проведення операції з відновлення українського контролю над російсько-українським кордоном. Слід підкреслити, що окупаційна адміністрація при політичній підтримці Росії, 3 одного боку, і Україна - 3 іншого, фактично мають на увазі під потенційним зовнішнім втручанням різні регіони операцій: в одному випадку - це поділ по лінії бойового зіткнення в глибині української території, в іншому - контроль українсько-російського кордону.

Як результат на цьому етапі основними затребуваними миротворчими функціями міжнародних організацій на Сході України залишаються як силова розділова, так i спостережна. Перша вже (нехай поки й не дуже ефективно) здійснюється СММ ОБСЄ, друга може бути реалізована під політичним контролем ОБСЕ із залученням сформованих миротворчих підрозділів країн ЄС/ОБСС.

Євросоюз вважає свої миротворчі функції значною мірою виконаними за допомогою фінансової та організаційної участі в місії ОБСЕ i не планує додаткової власної миротворчої місії. ОДКБ стримується від надання своїх недавно сформованих Колективних миротворчих сил політичною неготовністю ряду країн ОДКБ створювати прецедент втручання в ситуацію боротьби центральної влади країни із сепаратизмом.

Ставлення РФ до можливості i необхідності подальшої інтернаціоналізації конфлікту за допомогою додаткового залучення тих чи інших міжнародних організацій залишається в цілому негативним, проте еволюціонуе в напрямі визнання можливості надання поліцейських функцій місії ОБСЕ і повнішої реалізації іiї наглядових повноважень.

У цілому це відповідає формату операції 3 постконфліктного відновлення (post-conflict reconstruction). Цей формат склався в арсеналі $\mathrm{OOH}$ і регіональних міжнародних організацій (НАТО, ЄС, Африканський союз) в останнє 
десятиліття і зайняв одне 3 провідних місць в миротворчому арсеналі. Досвід операцій за мандатами ООН в Афганістані, Боснії, Косово (де операції на сьогодні відносяться саме до цього типу) показав, що існує певний “конвеєр" міжнародних організацій з погляду форматів їх участі у врегулюванні. На ранніх етапах конфліктів операції мають силовий характер 3 елементами примусових дій $\mathrm{i}$ потребують залучення озброєних військових контингентів 3 широкими повноваженнями. На наступних етапах після забезпечення припинення вогню в операціях знижується військовий i нарощується поліцейський i політико-дипломатичний компоненти, операції нерідко передаються, наприклад, від НАТО як провідного виконавця мандата $\mathrm{OOH}$ до Євросоюзу і ОБСЕ.

У цьому плані в конфлікті на Сході України застосування силового роз'єднання сторін “третьою силою” поки не відбулося. Слід виходити 3 того, що ситуація замороженого конфлікту може зберегтися відносно тривалий термін (що демонструють прецеденти невизнаних держав і заморожених конфліктів в регіонах Молдови/ Придністров'я, Північного Кіпру, Нагірного Карабаху тощо). У мінливих політичних умовах це може привести до актуалізації питання про миротворче втручання ззовні в різних форматах 3 боку як держав або їх коаліцій, так і міжнародних організацій

Висновки. Миротворча операція $\mathrm{OOH}$ на Сході України може забезпечити механізм дотримання Мінських домовленостей і вивести нинішню ситуацію на Донбасі з глухого кута. Така місія може перебувати під безпосереднім командуванням $\mathrm{OOH}$, або залучити незалежні військові Міжнародні коаліційні сили 3 поліцейськими та цивільними елементами, очолюваними ООН. Миротворча місія повинна мати широкий мандат, що включає:

забезпечення міцного миру та справжнього припинення військових дій i збройного конфлікту; активний моніторинг за ділянкою міжнародного кордону завдовжки 409 км.; контроль громадського порядку й цивільних аспектів реінтеграції в результаті виборів і опісля, щоб досягти максимальної довіри місцевого населення до цього процесу;

забезпечення виборів у регіоні для розблокування прогресу виконання Мінських домовленостей.

Для забезпечення миру миротворчим силам потрібно: мати у своєму складі до 20 тис. осіб, у тому числі 5 тис. осіб мають перебувати на міжнародному кордоні, щоб стежити за потенційними вторгненнями;

складатися 3 держав, що не входять до НАТО, які прийнятні як для України, так і для Росії. Серед них можуть бути Білорусь, Казахстан, Монголія, а також Австрія, Фінляндія або Швеція, так само як і низка Південноамериканських держав. Водночас до складу миротворчих сил можуть входити й деякі члени НАТО, які сприймаються Росією як дружні, тобто такі як Греція;

мати мандат на обмежене застосування сили для захисту цивільних осіб і мирного процесу, а також стримування тих, хто йому заважатиме.

Сили треба розділити на п'ять бойових груп, а для їх забезпечення використовувати вертольоти.

Для реалізації компромісів спеціальний представник Генерального секретаря $\mathrm{OOH}$ має бути погоджений усіма сторонами конфлікту.

Щоб зробити можливими передбачені Мінськими домовленостями вибори, миротворцям необхідно:

створити безпечне середовище для участі в передвиборній кампанії кандидатів від усіх діючих партій;

мінімізувати залякування та зловживання в день виборів;

переконатися, що остаточні результати $\epsilon$ достовірними й справедливими.

Крім того, для миротворчої місії на Сході України будуть потрібні значні сили поліції від 2 до 4 тис. осіб, включно із загонами, які спеціалізуватимуться на контролі місцевих сил безпеки, реакції на суспільні заворушення й перенавчанні місцевих співробітників сил безпеки. Така потреба сформульована 3 урахуванням досвіду Косова та Східної Словенії, який продемонстрував, що міжнародні збройні сили не можуть підтримувати громадський порядок i потребують допомоги поліції.

3 огляду на історію розгортання поліцейських операцій і верховенства закону, ЄC може стати ключовим у цивільних i поліцейських аспектах місії, а також у наданні гуманітарної допомоги. Для розв'язання соціально-економічних проблем місії знадобляться гуманітарні установи, експерти, юристи, фахівці зі зв'язків із громадськістю, в галузі державного управління, посередники для роботи 3 місцевими громадами над постконфліктним відновленням і реінтеграцією в державні структури України. 
Надалі

логістичного розглядатимуться варіанти забезпечення миротворчої операції ООН на Сході України.

\section{СПИСОК ВИКОРИСТАНОЇ ЛІТЕРАТУРИ}

1. Президент України і Генеральний Секретар ООН дійшли згоди про миротворчу місію. - Режим доступу: https://www.radiosvoboda.org/a/ news/29045105.html

2. Munich Security Conference. - Режим доступу: https://www.securityconference.de/en/activities/muni ch-security-conference

3. Тарасенко Н. Миротворча місія ООН як спосіб вирішення конфлікту на Донбасі: оцінки експертів. Україна: події, факти, коментарі. 2018. - № 5. - С. 24-38. - Режим доступу:http://nbuviap.gov.ua/images/ukraine/2018/ ukr5.pdf

4. Закон України від 18.01.2018 № 2268 “Про особливості державної політики із забезпечення державного суверенітету України на тимчасово окупованих територіях у Донецькій та Луганській областях".
5. Мінські домовленості. Деталі та подробиці. Режим доступу: https://mfaukraine.wordpress.com/ 2016/03/28

6. Іващенко А. М., Голопатюк Л. С., Розумний О. Д. Аналіз змін стратегії миротворчої діяльності Організації Об'єднаних Націй. Зб. наукових праць ЦВСД НУОУ. - № 3(58), 2016 p.

7. Возняк С. М., Іващенко А. М., Федянович Д. Л. Оцінка спроможностей ООН щодо врегулювання конфлікту на Сході України. Тези доповіді на II Всеукраїнській науково-практичній конференції "Українське суспільство в умовах війни: виклики сьогодення та перспективи миротворення" 15 червня 2018 р., Донецький державний університет управління (м. Маріуполь).

8. Возняк С. М., Іващенко А. М., Полякова О. В. Місія можлива. Оборонний вісник. - № 6, 2018. C. $10-15$.

9. Іващенко А. М. Миротворча діяльність ООН: адаптація до сучасних умов і концептуальні зміни Міжнародні операції 3 підтримання миру i безпеки: 25 років участі Збройних Сил України: зб.матеріалів міжвідомчого наук.-практ. семінару, НУОУ імені Івана Черняховського, 22 листопада 2017 р., м.Київ, С. 26-27.

Стаття надійшла до редакції 03.07.2018

Иващенко А. М., к.т.н., доцент;

Возняк С. Н., к.т.н., с.н.с;

Полякова Е. В.;

Зайцев Н. Н., к.ю.н.

Центр военно-стратегических исследований Национального университета обороны Украины имени Ивана Черняховского, Киев

Анализ возможных форм и способов проведения миротворческой операции на Востоке Украины

Резюме. Проводится анализ возможностей ООН по проведению миротворческой операции с целью урегулирования конфликта на Востоке Украины.

Ключевые слова: конфликт на Востоке Украины; ООН; миротворческая операция.

A. Ivashchenko, PhD, assistant professor;

S. Voznyk, PhD, senior researcher;

E. Polyakova;

N. Zajchev, Phd

Military Strategic Research Center of the National Defence Academy of Ukraine named Ivan Chernyhovskij

Analysis of possible forms and methods of conducting a peacekeeping operation in the East of Ukraine

Resume. An analysis of the UN's capability to conduct a peacekeeping operation to resolve the conflict in Eastern Ukraine is being conducted.

Keywords: conflict in the East of Ukraine; UN; Peacekeeping Operation. 